\title{
Michelangelo, Copernicus and the Sistine chapel
}

\author{
Valerie Shrimplin \\ 1 Monks Horton Way, St Albans AL1 4HA, United Kingdom \\ email: vshrimplin@dsl.pipex.com
}

\begin{abstract}
It is argued that Copernican astronomy is a key theme in Michelangelo's fresco of the Last Judgment in the Sistine Chapel, and was incorporated with the knowledge, consent and approval of the Popes concerned. In Christian art, the iconography of the Last Judgment (depicting the three parts of the universe: heaven, Earth and hell) was traditionally based on a layered structure relating to perceptions of the flat Earth covered by the dome of heaven according to biblical cosmology. In Michelangelo's revolutionary work, Christ is significantly depicted as a beardless Apollonian Sun-god, positioned in the centre of a dramatic circular design rather than at the top of a layered format. This appears to relate to the traditional Christian analogy between the deity and the astronomical feature of the sun, the neoplatonic cult of Sun-symbolism and sources in Dante. More importantly, the influence of the Copernican theory of heliocentricity is argued, since interest in such ideas in papal circles is demonstrated at exactly the time of the commission of the painting (1533). This provides important evidence of papal support for Copernican heliocentricity as early as the 1530s.
\end{abstract}

Keywords. Art, Copernicus, Michelangelo, Sistine Chapel, Dante

The Sistine Chapel, part of the complex of St Peter's in Rome, was built on the site of an earlier thirteenth century chapel in 1475. Cosmological associations of the chapel are evident since it measures 40.93 metres by 13.41 metres wide (threescore cubits by twenty cubits), that is, the precise dimensions given in the Bible for the temple of Solomon (1 Kings 6 ), which was in turn was widely held to have been made in imitation of the shape of the universe. The Chapel ceiling (painted by Michelangelo 1508-12) is well known for the depiction of the creation, according to Genesis, of light and dark, of the universe, the planets and humanity. On the altar wall, Michelangelo's monumental fresco of the Last Judgment (painted much later, 1536-1541) by contrast depicts the end of the universe. The overriding theme of the chapel is thus "the Beginning and the End" of the universe, the planet and humankind. Interpreted in terms of "Creation and Last Judgment", rather than the modern "Big Bang and gravitational collapse", the problems remain the same to be grappled with, even if the solutions or interpretations vary showing, again, an overriding cosmic theme to Michelangelo's frescoes in the Sistinet.

Michelangelo's fresco of the Last Judgment could easily lay claim to being the single most significant painting in the world and the immense importance of the fresco was immediately recognised by Michelangelo's contemporariesł. Almost as soon as it

$\dagger$ The present paper is a summary of work completed some time ago and thanks are expressed to the IAU Symposium 260 Scientific Organising Committee for the symposium to enable me to present it again here. I am particularly grateful for and would like to acknowledge IAU Symposium 260 assistance with the registration fee. All ideas mentioned here are fully explored and explained in Shrimplin (2000), based on my doctoral thesis of the same title, University of the Witwatersrand, 1991.

$\ddagger$ Michelangelo Buonarroti, Last Judgment, fresco, Sistine Chapel, Vatican, Rome, painted 1536-41 $(13.7 \times 12.2$ metres; $45 \times 40$ feet $)$. 
was completed and 'unveiled' on All Saints' Eve, 31 October 1541, Michelangelo's Last Judgment became a focus for controversy as well as admiration. Michelangelo's contemporary, the Venetian critic Pietro Aretino was not alone in his comments on its allegorical and hidden meaning, when he observed in 1545 that 'Michelangelo has imitated those great philosophers who hid the mysteries of human and divine philosophy under a veil, that they might not be understood by the vulgar". Literally hundreds of writers have attempted to "decode" and explain the fresco and its hidden symbolism ever since $\uparrow$.

The main argument here is that Copernican astronomy is a key theme in the fresco, and was intentionally incorporated by Michelangelo, with the knowledge, consent and approval of the popes concerned. Judæo-Christian cosmology, or the view of the universe, was traditionally reflected in Church art and architecture, for example in Christian domed architecture which was imitative of natural eye perceptions of the flat Earth covered by the dome of heaven. This was particularly relevant in depictions of the Last Judgment where complex ideas concerning heaven, earth and hell, and the fate of humanity, were illustrated together in a single image, in a distinctly layered design. In innumerable examples of the Last Judgment, the three parts of the known universe, heaven Earth and hell, would be depicted in relation to the concept that all would be judged -as the 'good' would ascend to heaven as the 'bad' would be sent down into hell- an effective disciplinary message in the absence of effective judicial systems.

Michelangelo's dramatic circular design, focussed on the central figure of Christ depicted as a beardless Apollonian Sun god varies enormously from traditional versions of the Last Judgment. Lines which could be construed as descriptive of Michelangelo's fresco:

In the midst of all assuredly dwells the Sun. For in this most beautiful temple who would place this illuminary in any better position ... some call him the Light of the World ... So he remains, governing the family of Heavenly bodies which circles around him.

actually come from Copernicus (1543)'s Revolutions, Book 1, chapter 10. Yet Copernicus' book was published in 1543, two years after the great fresco was completed and clearly many years after it was commissioned and designed. Because of the discrepancies in dating of De Revolutionibus and dating of Michelangelo's fresco, the possibility of a link between the two was never seriously and fully explored. The art historian Charles de Tolnay wrote:

By means of the central place which Michelangelo reserved in his composition for the Sun (Christ-Apollo) .. The artist came of himself to a vision of the universe which surprisingly corresponds to that of his contemporary Copernicus. Yet he could not have known Copernicus' book which was published in 1543 -at least 7 years after Michelangelo conceived his fresco. De Tolnay (1943-1960)

The analogy between Christ and the Sun and the possible influence of Copernicus' theory was seen as impossible because the publication date of the book postdated the completion of the fresco. However if we look at the sort of sources used by Michelangelo -Christian theology, classical and Christian iconography, Dante, neoplatonism and, arguably, contemporary scientific theories- a case can be made for the undoubted influence of Copernicus' heliocentric theory on the fresco.

Typical images of Apollo, such as the Apollo Belvedere (Greek, 2nd century BCE, found in Italy in 1489), had been common in the Italian Renaissance, many such examples being rediscovered in Renaissance Florence and Rome at the time when Michelangelo was working there. An affinity with this type of image is very clear in Michelangelo's design. The concept of Christ as an Apollo-type figure was common in the early days of

I For a good summary of Michelangelo and his works, see Murray (1984). 
Christianity, as a way of encouraging converts - and the idea of Christ as the Sun or the light of the world is demonstrated by innumerable biblical references (particularly in the Gospel of St John, especially 1:1-10 and 8:12).

The links between astronomy and Christian iconography can also be securely established, for example in the starred, domed ceiling mosaic of the mausoleum of Galla Placidia at Ravenna (c. 425) which echoes the flat earth view, covered by the dome of heaven (Lehman 1971). The mosaic of God creating the world at Monreale (1175) is another instance where the cosmic meaning is clear, and the creation cycle in St Mark's Venice (11th century) also demonstrates the view of the cosmos in relation to its creation as part of the Christian tradition. These few examples serve to demonstrate the important links between Christian iconography and astronomy. Another area is that of orientation in Christian architecture. The East-West orientation of Christian Churches, with the altar in the east, is well known. The basilica of St Peter's in Rome is exceptional since, situated to the West of Rome, the entrance faces Rome itself in the East. Few churches have their altars in the West, but it seems that the reason for this at St Peter's was because the original basilica was built by the Emperor Constantine on an earlier foundation of a pagan Sun temple where the aim was for the rising Sun to enter the doorway. The Last Judgment in turn was normally placed on the West of a church -to face the setting Sun- and located in that area in the West, as a stern reminder to the congregation on exit. The Sistine chapel has the same orientation at St Peter's so Michelangelo's Last Judgment is unusually placed on the West (but significantly the altar) wall of the chapel.

Before the Sistine chapel (begun the year Michelangelo was born) was redecorated in late fifteenth and early sixteenth century by Michelangelo and others, it was known to have been decorated with a simple blue ceiling, covered in stars, thus again establishing an astronomical connection. In addition, the links between the view of the Last Judgment and the arrangement of the known universe were also extremely well established. A good example is the sixth century manuscript by the Syrian monk Cosmas Indicopleustes in his Christian Topography†. This includes a version of the Last Judgment with Christ situated at the top and various ranks of humans, saints and angels ascending to heaven and descending to hell in a strict hierarchy. Significantly, there is a drawing of the universe in the same manuscript which clearly relates to the same layered format, showing an immediate and obvious relationship between the view of the universe and the concept of the Last Judgment. Apart from manuscript versions, this basic format for the Last Judgment can be seen in innumerable examples, in the tympana of the great French cathedrals (for example Vezelay, 1125), and in earlier Italian frescoes, such as Giotto's version at Padua (c 1305-7). The hierarchical framework is very clear in Giotto's work -in spite of the intrusive window. But Michelangelo changed all this, introducing a revolutionary new design. There are features of the old traditions still remaining in Michelangelo's work but, filling in the former window to make one vast space, a huge circular movement overcomes and warps into features of the traditional design.

At this point it is important to remember the idea of the centre of the universe which is shown in the flat Earth system as Jerusalem, in accordance with Ezekiel 5;5. This is clear in many so-called $T$-and- $O$ maps, but there is evidence that the old idea of the Sun-centred universe, as proposed by the ancient Greeks, such as Aristarchus, never

$\dagger$ Cosmas Indicopleustes, Christian Topography (Vat. Gr. 699), cross-sectional diagram of the Universe, and depiction of the Last Judgment, sixth century. Vatican Library, Rome. Two out of the three surviving manuscripts were in Rome and Florence during the late fifteenth and early sixteenth century, where Michelangelo could have had access. 
completely died out $\ddagger$. The "astronomer" Pope Gerbert had raised such ideas in c. 999. However, in general, it was the geocentric concept of the Earth that displaced the flat Earth view of the universe in Western Europe in the middle ages (as illustrated in fifteenth century Florentine manuscripts such as the Diagram of the Cosmos 1038, 240v in the Biblioteca Riccardiana, Florence). This was generally perceived by educated persons, yet the problem here was that if the idea of a circular universe with the Earth at the centre was combined with the Biblical concepts of 'up for heaven' and 'down for hell' then hell would appear to take the central place in a 'haidocentric' universe This was clearly unacceptable and somewhat difficult to deal with. Dante therefore, in his Divine Comedy therefore selects a 'dual' system for his universe. Dante (and his illustrators) firstly present a terrestrial system with Lucifer at the centre (as in the manuscript of the Topography of Hell, Florence c 1575). In fact, the precise centre of hell is defined in Inferno 34 as the point at which Dante and his companion Virgil descend down the figure of Lucifer, then turn (at the point of Lucifer's thigh) in order to start ascending again towards the surface of the Earth's sphere. This view of hell in the centre of the earth contrasts with Dante's separate circular system in the Empyrean, focussed on a point of light - depicted in Botticelli's illustrations for the Divine Comedy as a 'Sun-Christ' figure (Dante Alighieri 1984). Michelangelo was well known as an expert on Dante and would undoubtedly have been familiar with Dante and the issues that were raised here. His own poetry and that of his friend Vittoria Colonna also include very many references to Christ as the Sun -and, lest any complex association be dismissed-it is important to remember that Michelangelo always avowed "I paint with my brains, not with my hands."

Similarly, Michelangelo -growing up as he did under the patronage of Lorenzo de Medici- was also an expert on neoplatonism and the works of Marsilio Ficinot. Until Ficino translated Plato's oeuvre form the Greek, few of Plato's works had been known through the medieval period, the exception being the Timaeus which is well know for its theme of cosmology. The importance of this work in the early sixteenth century is demonstrated by the fact that in Raphael's famous School of Athens, the figure of Plato holds this very volume under his arm. Michelangelo would therefore have been familiar with works by neoplatonic philosophers such as Ficino, Poliziano and Landino, which focus on interpretations of Plato's cosmology and, of course, the concept of the light as the Good (according to Republic VI). Ficino continuously draws analogies between God and the Sun -and in fact his ideas were said to have influenced Copernicus. Ficino's book De Sole was required reading in Krakow when Copernicus was a student there.

Set against this context of Renaissance scholarship, it is important to remember that Copernicus was influenced by similar ideas since he spent at least seven years in Italy in a very similar environment to Michelangelo (Kuhn 1957; Rosen 1971). The idea of any relation between Copernicus' ideas and Michelangelo's fresco had always been discounted because of the dating, but closer investigation reveals (which is evidently more well known amongst astronomers than art historians) that Copernicus actually received the first copy of his book whilst on his death bed in 1543, at the age of 70. Born in 1473, he was almost exactly contemporary with Michelangelo, and information about his ideas and reputation had been growing and circulating from as early as 1500 . He was invited to give talks in Rome in 1500 (when Michelangelo was also in Rome) and other publications such as the Commentarioulus (1514) and the Letter against Werner (1522) circulated long before

$\ddagger$ It appears significant that the ancient heliocentric theory as proposed by Aristarchus of Samos was mentioned by Vitruvius in his famous Ten Books on Architecture, with which Michelangelo was undoubtedly familiar.

I haidocentric (meaning hell-centric) derived from the Greek word for hell, 'haides'.

$\dagger$ For Ficino and the neoplatonists, see in particular Ficino (1985) and Cassirer (1963). 
the conception of the fresco. There is a great deal of additional evidence (for example comments made by Martin Luther) that Copernicus' ideas about the Sun as the centre of the universe were circulating widely in the 1530s, if not the 1520s (Kuhn 1957). It thus becomes clear that (since it was not necessary then as now for anyone actually to read Revolutions in order to grasp the heliocentric idea) it would have been very unlikely for Michelangelo not to have heard of Copernicus and his ideas. Copernicus' fame had spread and he is allegedly portrayed in Giorgione's painting of the Three Philosophers (which Giorgione painted in 1509, assisted by Sebastiano del Piombo -who also, coincidentally, helped Michelangelo in the early stages of preparations for the painting of the Last Judgment). The first reference to a commission for the Last Judgment was also made by Sebastiano, in July 1533. He wrote to Michelangelo that the Pope (Clement VII who was also a Medici and had known Michelangelo since childhood) had plans for a grand design in the Sistine Chapel.

What makes Copernican influence very clear, however, is that at exactly this time, Pope Clement VII requested that Copernicus' theories "concerning the motion of the Earth" should be explained to him at a special lecture to a group of dignitaries in the garden of the Vatican in June 1533. This event was recorded by the lecturer, Albert Widmanstadt inside the cover of a precious manuscript that the Pope gave him to mark the occasion: "Clement VII presented this codex to me, AD 1533 after I had, in the presence of Fra Ursino, Cardinal Joh. Salviati, Joh.Petrus Bishop of Viterbo and Matthias Curtius, medical physician, explained to him in the garden of the Vatican, Copernicus' teaching concerning the motion of the Earth. Albertus Widmanstadius" $\dagger$.

Widmanstadt (who coincidentally was the protégé of Egidio da Viterbo who had advised Michelangelo on the painting of the Sistine ceiling) was a colleague of Theodoric of Radzyn, the representative of Copernicus' chapter of Varmia in Rome, so a direct link is easily traceable between Michelangelo and Copernicus at the time of the commission of the Last Judgment. The dating of the Vatican lecture can be secured by the reference to Johannes Petrus, Bishop of Viterbo since we know this appointment was made in summer 1533. Salviati, also present, was a close friend of Michelangelo. It is also well documented that Clement VII was in Rome that summer until he left in September on his way to France, during which time he met Michelangelo near Pisa to discuss the commission for the fresco (22 September 1533). So the Pope commissioned the fresco right after he had had Copernicus' heliocentric hypothesis explained to him by a professional lecturer. Michelangelo's early drawings for the fresco suggest a circular design and astronomical referencesł, and further evidence exists of Vatican interest in Copernican astronomy at this time. The famous letter of Cardinal Schoenberg to Copernicus in 1536 appears to be an urgent request for further information as the painting of the fresco got underway in summer 1536: "Several years ago word reached me ... I had learned that you had formulated a new cosmology; you maintain that the Earth moves, that the Sun occupies the most central place in the universe ... I entreat you to communicate this discovery of yours to scholars." (Cardinal Schoenberg, 1536, this letter was included in the printed version of Revolutions in 1543.). Clement VII had died by this time but the next Pope, Paul III Farnese (who had also grown up in the Medici household in Florence) supported the project. He was, significantly, the very Pope to whom Copernicus' Revolutions was dedicated in 1543.

$\dagger$ Bayersiche Staats Bibliothek Munich, Codex Graecus Monacensis, 151, and see von Pastor (1901-28) and Prowe (1883).

$\ddagger$ The Bayonne drawing, 1533 shows a clearly circular design, whilst the Buonarotti drawing (1534) alludes to the Virgin Mary in accordance with Revealtion 12 "a woman clothed with the Sun and the Moon under her feet, and upon her head a crown of 12 stars." 
Table 1.

\begin{tabular}{llll}
\hline \multicolumn{2}{c}{ Copernicus 1473-1543 } & \multicolumn{1}{c}{ Copernicus 1475-1564 } \\
\hline $1491-94$ & Cracow & 1496 & Bologna \\
$1496-03$ & Bologna & 1500 & Rome \\
1500 & Rome & $1500-34$ & Rome/Florence \\
1514 & Fifth Lateran Council, Copernicus's & 1533 & 17 July "a contract ..." \\
& advice sought & & \\
1524 & Letter against Werner circulating & 1533 & Bayonne drwaing of LJ \\
1531 & Satires on Copernicus & 1534 & Buonaroti drawing of LJ \\
1533 & Lecture in Vatican (June) & 1534 & returns to Rome (sept); Clement dies \\
1536 & Schönberg's letter & 1534 & Paul III becomes pope \\
1539 & Luther against Copernicus & 1536 & painting commenced (Apr/May) \\
1540 & Narratio prima & 1536 & 17 Nov, papal breve on LJ \\
1541 & Second edition of Narratio prima & 1541 & 31 Oct, completion/unveiling \\
1542 & Revival of Inquisition & 1542 & Pauline frescoes commissioned \\
1543 & Death, Revolutions & 1543 & Superintendent for frescoes \\
$1544-45$ & Opposition to Revolutions commences & 1545 & Opposition to Last Judgment com- \\
& & & mences \\
\hline
\end{tabular}

Although illustrations of the fresco prior to the cleaning and restoration in the early 1990s show it with a dark and desperate atmosphere, caused by smoke from the candles, the cleaned and restored fresco is amazingly lighter and brighter. Contemporary copies (such as that by Martinus Rota, 1569) demonstrate that this was much closer to the original state of the fresco and thus clearly fits in with the concept of sun and light symbolism in the fresco (see Mancinelli et al. 1990, for information on the cleaning and restoration).

A summary of key dates - relating both to Michelangelo, Copernicus and the fresco itself- demonstrates significant overlap and coincidence (Table 1).

Michelangelo was nurtured on Catholic views of Christ as the light (Sun), imbued with Ficino and Dante and then commissioned to paint what was traditionally a cosmological subject at exactly the time that the theories of Copernicus (himself imbued with Italian Renaissance and neoplatonic thought) were attracting huge attention in the Vatican. To return to the concept of the central point of the universe, it is interesting to consider what might be the central point in Michelangelo's design. A formal visual analysis of the painting itself can reveal this, since in order to obtain the circularity of the design on such an immense area (the wall is over 17 metres high), a device such as a rotating plumb line would have been used. Surprisingly, the centre of both the circular movement and the focus of diagonal lines does not lie on Christ's head or heart, but is evidently lower down. The centre of the design is actually focussed on Christ's right thigh. A reason for this is to be found in the book of Revelation, 19:16 which reads "and on his vesture and on his thigh was a name written, KING OF KINGS and LORD of LORDS.". The next verse significantly begins "and I saw an angel standing in the Sun". Thus Christ is depicted as Michelangelo viewed him -King of Kings and Lord of Lords, the Sun the centre of the universe.

Copernicus' heliocentric theory appears to have acted as a precipitating factor to cause a number of existing concepts to fall into place. His scientific thinking appears to have been absorbed into popular thinking and it was no more necessary for those who were interested to read his actual book, anymore than many, nowadays, who talk about relativity have actually read anything by Einstein. In this year of celebration of Galileo's astronomical use of the telescope, we can remember that it was not until 1616, 
over 70 years since its first publication, that Copernicus' Revolutions was placed on the Index of Prohibited Books. The transition from the flat Earth concept (with Jerusalem as centre) to geocentric, haidocentric, heliocentric -and more recently galactocentricand now a-centric (expanding with no real centre) views of the universe all add to our understanding and the importance of consideration of humanity's place in the universe. Due to Copernicus' theory, the position of humanity, in a geocentric universe, had been displaced from a central position but surely the idea of placing God personified as the Sun at centre was far more logical instead. In a view characterised by its elegant simplicity, this concept appears to be most logical. Although Copernicus' theory was later condemned, when the wider implications were acknowledged following the work of Galileo, during the 1540 s this was quite simply not the case. At the time that Michelangelo was painting his great fresco, the heliocentric theory appears to have generated more interest and support from the Catholic Church at this time than previously recognised. As interpreted by Michelangelo in his Last Judgment fresco, the traditional analogy between Sun and Deity was vindicated at last.

\section{References}

Alighieri, D. 1984, The Divine Comedy, transl. A Mandelbaum, 3 vols. (New York: Bantam Press)

Cassirer, E. 1963, The Individual and the Cosmos in Renaissance Philosophy (Oxford: Blackwell)

Copernicus, N. 1543, De Revolutionibus Orbium Coelestium, J. Dobrzycki (ed) 1968 (London: Macmillan)

de Tolnay, C. 1943-1960, Michelangelo, 5 vols. (Princeton: Princeton University Press), Vol 5: 49 and 122

Ficino, M. 1985, , De Amore, Commentary of Plato's Symposium on Love (Dallas: Spring Publishers)

Kuhn, T. S. 1957, The Copernican Revolution. Planetary Astronomy in the Development of Western Thought (Cambridge: Harvard University Press)

Lehman, K. 1971, in Modern Perspectives in Western Art History (New York: Holt, Rinehart and Winston), pp. 227-270

Mancinelli, F. et al. 1990, Michelangelo e la Sistina. La Technica, il restauro, il mito (Rome: Palombi)

Murray, L. 1984, Michelangelo, His Life, Work and Times (London: Thames \& Hudson)

Prowe, L. 1883, Nicholas Copernicus (Berlin: Weidmannsche Buchhandlung), Vol 1, p. 273

Rosen, E. 1971, Three Copernican Treatises (New York: Octagon Books)

Shrimplin, V. 2000, Sun-symbolism and Cosmology in Michelangelo's Last Judgment, Sixteenth Century Essays and Studies, vol. 46 (Kirksville: Truman State University Press)

von Pastor, L. 1901-1928, History of the Popes, 24 vols. (London: Routledge \& Kegan Paul), Vol. 10, p. 336, and Vol. 12, p. 549 